Journal of Contemporary Research in Social Sciences

ISSN : 2641-0249

Vol. 2, No. 2, pp. 26-34

2020

Publisher: Learning Gate

DOI: 10.33094/26410249.2020.22.26.34

(C) 2020 by the authors; licensee Learning Gate

\title{
Do Corporate Social Responsibility Activities Influence Employees’ Job Performance?
}

\author{
Sunday Otuya \\ Department of Accounting \& Finance, Edwin Clark University, Kiagbodo Delta State, Nigeria. \\ Email: otuya.Sunday@gmail.com \\ Fidelis Akporien \\ Department of Accounting, Faculty of Management Sciences, Nnamdi Azikiwe University, Awka Anambra State, Nigeria. \\ Email: Fidelisco.akp@gmail.com
}

Received: 16 April 2020; Revised: 30 April 2020; Accepted: 12 May 2020; Published: 27 May 2020

\begin{abstract}
The study investigated the influence of corporate social responsibility activities on employee job performance of listed food and beverages companies in Nigeria. The study, anchored on the Social Identity Theory, adopted the content analysis approach and obtained panel data from financial statements of sampled companies for the period 2014 to 2018. The study deployed descriptive, correlation and regression analyses as data analytical techniques. The findings indicated that employment of physically challenged, expenditure on staff training and development, and community based projects have a positive and significant association with employees' job performance. The study further revealed that monetary donations and gifts to charity organisations and NGOs have a significant negative relationship with employees' job performance. The study concludes that corporate social responsibility practices enhances job performance of employees and recommends amongst others the need for corporate managers to properly recognize the type of CSR activities that their employees respond favorably to since not all CSR activities motivate employee job performance.
\end{abstract}

Keywords: Corporate social responsibility, Employee Job performance, Food, Beverages companies, Community based projects, Expenditure on staff training, Development, Monetary donations, Gifts.

\section{Introduction}

Corporate organisations are increasingly engaging in social responsibility activities as part of stakeholders' engagement by giving back to the society, upholding ethical values and protecting natural environment. Due to the increased awareness associated with sustainability reporting, companies are becoming socially responsible by not only focusing on making huge profits at the expense of the the environment but also taking care of the people and environment where they carry out the business activities.

Omer (2018) companies deploy different human and natural resources from the environment for business operations to generate profits. The production activities deplete natural resources and also cause a negative impact on natural environment. In view of this, researchers and policy makers are asking that businesses should not only focus on profit generation but also contribute to economic development and behave ethically for the improvement of society by doing CSR activities. Consequently, companies are now more than ever before engaging in community development activities in the developing world. More companies are now working for the good or wellbeing of the society by giving donation to schools and hospitals etc. 
CSR is gaining considerable importance and has become an effective strategy adopted by corporate organizations for sustainable organizational development. Many organizations are involved in providing social, environmental and economic benefits to different local communities worldwide. In Nigeria for instance, several national and multinationals organizations such as Dangote, Chevron, Shell, MTN, Guinness, Seplat, etc, are engaged in various CSR activities in collaboration with different government agencies and NGOS. These activities are aimed at providing education to reduce illiteracy rate, improving labour standards in the country and providing basic health facilities especially in the under developed areas of the country (Adeyemo, Oyebamiji, \& Alimi, 2013; Edike \& Otuya, 2018).

Studies (Gond, El-Akremi, Igalens, \& Swaen, 2019; Sarfraz, Qun, Abdullah, \& Alvi, 2019) have noted that CSR activities address the needs of various stakeholders of the business including employees. Employees' performance is considered a vital issue for companies who view their workforce as their greatest asset. Shahin, Naftchali, and Pool (2014) contend that CSR address employee commitment, satisfaction, performance and productivity challenges. Organizations are therefore in search of people who will go beyond their defined career duties, develop cooperation, and help colleagues, employers, and customers.. As a result, it is important for organizations to create a culture and atmosphere that facilitate employee commitment, productivity and overall organizational performance.

\subsection{Objectives of the Study}

The main objective of the study is to investigate the influence of corporate social responsibility activities on employee job performance. The specific objectives are to:

i. Determine the effect of Monetary Gifts and Donations on employee job performance.

ii. Examine the effect of Employment of Physically Challenged on employee job performance.

iii. Investigate effect of Employee Training and Development on employee job performance.

iv. Find out the effect of Involvement in Community Based Project on employee job performance.

\section{Literature Review}

\subsection{Corporate Social Responsibility}

CSR is defined as context-specific organizational actions and policies that take into account stakeholders' expectations and the triple bottom line of economic, social, and environmental performance. It has been described by World Business Council for Sustainable Development (2001) as an environmental and social awareness of a firm carried out as a business commitment to contribute towards a sustainable economic development, work with employees, also with their families and local communities.

Rahman (2011) views CSR as activities that engage companaies with the society and as a process by which a corporations develop their social awareness and corporate culture. CSR activities cover different scopes like ethical practices, economic improvement, stakeholder's involvement, environmental protection, responsible behavior, accountability, moral obligations, and corporate responsiveness.

\subsection{Employee Performance}

Employee performance is the ability of a company's employee to achieve set goals in line with the overall objectives of the company. Employees' performance is a critical factor for the overall success of the company hence corporate managers need employees that are able to get the job done. Greening and Turban (2000) posit that employees' performance and productivity to a large extent affect the ultimate attainment of the firm broad objectives. Employee job performance encompasses factors such as quality, quantity and effectiveness of work as well as the behaviors employees show in the workplace. Understanding performance metrics, employee performance review methods and ways to improve performance will help corporate managers ensure that the workforce can meet business's and customers' needs (Lei, 2011).

Companies usually set performance targets for individual employees and the company as a whole in hopes that the firm offers good value to customers, minimizes waste and operates efficiently. 
Corporate managers in this $21^{\text {st }}$ century business environment have realized that for business to grow and survive, it must have high performing workforce.. Therefore, productivity of the workforce has become a top priority for corporations as a highly productive workforce increases innovation, output, and bottom line performance while decreasing costs of production (Harvard Business Review, 2013).

\subsection{Empirical Review}

Empirical research on the link between CSR and employee performance have given a lot of varied and heterogeneous results. Omer (2018) in a study in an exploratory study examines the impact of corporate social responsibility (CSR) on employee job satisfaction. The study aims of check the availability of CSR activities and evaluates its effect in the hospital. A questionnaire involving of eight items and was distributed among the employees of Paky hospital randomly. The study used One-Sample Statistics t-test and ANOVA to test the validity of hypothesis. The main conclusion of the study is that there is an insignificant effect of CSR activities on job satisfaction of employees in Paky hospital; as well some of the elements or activities of CSR and job satisfaction are shared in the hospital.

Alkayed (2017) examines whether CSR has a positive effect with businesses job satisfaction especially with services introduce by the organization toward employees. The study focused on a Jordanian private hospital using a survey research design. Analysis of 84 suitable responses among private hospitals employees found a significant effect CSR on job satisfaction at the two hypotheses. Kilong'i, Ayora, and Butali (2019) study was to find out the effect of corporate social responsibility on organization performance of bottled water companies in Garissa County, Kenya. The study made use of a survey research design with the target population of 100 using census sampling technique. The findings from the study indicated that there is a positive significant effect between CSR and organization performance.

Shuli and Suwandee (2017) in a study adopted Social Responsibility Theory (CSR Theory) and Social Identity Theory (SIT) to examine the link between employees perception of CSR activities, organizations influence and employee job performance. The study employed a quantitative design and distributed questionnaire to 281 staffs working in household products manufacturers in southern China. Findings of the study showed that employees perception of CSR activities have positive influence on their job performance.

Tsourvakas and Yfantidou (2018) examined the effect of CSR on employee job satisfaction, motivation and engagement using employees of two companies in Greece. Using a quantitative approach, findings of the research indicated that employees are proud to identify themselves with companies that have a caring reputation. CSR was also seen to be positively associated with employee engagement for both companies. The study therefore suggested that it would be helpful for corporate managers to design CSR strategies and ensure employees' involvement in planning and execution of corporate strategies.

Setyaningrum and Haryono (2018) in a study aim to determine how CSR affects employee performance and the role of employee trust and employee behavior as a mediator at 3 companies in Bekasi and Jakarta. The research questions in this study are: the impact of CSR on employee performance; the impact of CSR on employee trust; the impact of employee trust on employee performance; the impact of CSR on employee behavior and the impact of employee behavior on employee performance. The sample used in this study was 246 employees from companies in Bekasi and Jakarta District. Data collection method used in the study was questionnaire and forum group discussions while analytical method used was SEM Warps PLS. The findings of the study indicate that CSR does not impact directly on the employee performance. CSR is also found to influence employee trust, while employee trust significantly impacts on employee performance. CSR also has a significant effect on employee behavior, while employee behavior in turn affects employee performance significantly.

Peong (2019) examine the effect of Corporate Social Responsibility and talent management on employee engagement in Tirta Komodo Regional Water Company (PDAM), East Nusa Tenggara 
(NTT), Indonesia. The data collection in this research was conducted through closed questionnaires consisting of 40 statement items. The sampling was done using proportionate random sampling. The number of samples was 120 employees at the Head Office of Tirta Komodo Regional Water Company NTT. Data analysis techniques applied multiple regressions. Findings of the study indicate that the effectiveness level of implementation of social responsibility and talent management program has a positive and significant effect on increased employee attachment.

Sarfraz et al. (2019) explore the association between employee perception of CSR and employee's outcome in selected SMEs in Pakistan. The study further considered organizational justice as a mediating role on employee's perception of CSR and employee' outcomes. Data were collected data from 300 SME's. Findings of the study show a significant relationship between employee's perception of CSR and employee outcomes. Moreover, mediation analysis results show that organizational justice has an insignificant effect on employee's perception of CSR and employee's outcomes.

From the review of related literature, it can be observed that there is lack of unanimity on the relationship between CSR activities and employees' performance. Another gap is that most prior studies in the area adopted survey research design through use of self-structured questionnaires. This study makes a clear departure from previous studies by adopting a content analysis approach which uses information published in the financial statements of sampled firms. Further, studies on the effect of CSR on employees' job performance specifics are scarce in the developing world particularly Nigeria hence a need for a study in this area.

\section{Methodology}

\subsection{Design and Data}

The study involves the analysis of corporate annual reports hence content analysis approach which has been widely used in corporate social responsibility and sustainability reporting studies. The population of the study comprises of all food and beverages companies listed in the Nigeria Stock Exchange (2019). However, of the 17 food and beverages companies listed on the NSE as at $31^{\text {st }}$ December 2018, 10 were randomly selected for the period 2014 to 2018. Data collected were subjected to analysis through descriptive statistics, correlation and linear regression analysis.

\subsection{Theoretical Framework and Model Specification}

The Social Identity Theory is considered suitable for this study for the fact that the theory suggests that individuals tend to reinforce their self-esteem and bolster their self-image by identifying with groups and organizations recognized for their social engagement and responsibility. Social identity is a part of an person's self-concept gotten from supposed affiliation in a relevant social group. The theory posits that a company's employee's benefit from the firm's social reputation and identity by creating, upholding and improving his/her own identity (Dutton, Dukerich, \& Harquail, 1994).

Since long term corporate social performance enhances individual positive self-image for an employee, therefore, corporate organisations with long term, and effective social performance motivate their employees by encouraging positive behavior. A number of previous empirical studies have underlined how social identification clarifies how CSR activities influence employees job performance (Sarfraz et al., 2019; Setyaningrum \& Haryono, 2018; Shuli \& Suwandee, 2017).

Consequently, a model that captures the influence of corporate social responsibility activities on employees' job performance in Nigeria was developed for the study. The model is expressed as follows:

$E M P_{i t}=\beta_{o}+\beta_{i} M D G_{i t}+\beta_{2} E P C_{i t}+B_{s} E T C_{i t} B_{i} C B P_{i t}+e i t$

Where:

EMP = Employee Performance.

$\mathrm{MDG}=$ Monetary Donation and Gifts.

$\mathrm{EPC}=$ Employment of Physically Challenged.

ETC $=$ Expenditure on Staff Training and Development.

$\mathrm{CBP}=$ Community Based Projects. 
$\mathrm{e}=$ Stochastic or disturbance term.

$\mathrm{i}=$ companies.

$t=$ Time dimension of the Variables.

$\beta_{0}=$ Constant or intercept.

$\beta_{1-4}=$ Coefficients to be estimated or the Coefficient of slope parameters.

\subsection{Measurement of Variables}

3.3.1. Dependent Variable

The dependent variable is Employee job performance to be measured in terms of productivity. Productivity is measured as a proportion of input to output. In this study, input is derived as total salaries paid to employees while the output is total turnover for the year.

\subsection{Independent Variables}

The MDG variable tests for Monetary donations and gifts and it is obtained as log of total expenditure on donations and gifts to charity organisations, NGOs etc.

The study also examines Employment of Physically Challenged. It is derived by using the absolute number of physically challenged persons in the employment of the firm.

ETC stands for Employee Training and Development measured as total expenditure on staff training and development scaled by total operating expenses.

CBP stands for Community Based Project. This is measured as the number of community based project embarked upon by the company for the period examined.

\section{Estimation Results and Discussion of Findings}

Table 1

Descriptive statistics of the variables

\begin{tabular}{c|c|c|c|c|c}
\hline Statistics & EMP & MDG & EPC & ETC & CBP \\
\hline Mean & 0.103800 & 32.77400 & 4.600000 & 0.252600 & 7.400000 \\
\hline Maximum & 0.148000 & 79.90000 & 17.00000 & 0.467000 & 11.00000 \\
\hline Minimum & 0.069000 & 6.670000 & 0.000000 & 0.029000 & 3.000000 \\
\hline Std. Dev. & 0.028121 & 27.72059 & 6.534055 & 0.152821 & 2.899683 \\
\hline Observations & 50 & 50 & 50 & 50 & 50 \\
\hline
\end{tabular}

Source: Content analysis of financial statements.

KEY: EMP = Employee Performance; MDG = Monetary Donation and Gifts; EPC = Employment of Physically Challenged; ETC = Expenditure on Staff Training and Development; $\mathrm{CBP}=$ Community Based Projects.

Table 1 shows the mean, minimum, maximum and standard deviation scores of the variables. Employee Performance (EMP) is observed with a mean of 0.1038 with maximum and minimum values of 0.148 and 0.069 respectively. The standard deviation of 0.028 indicates that there is no considerable dispersion in reported productivity ratio among the sampled firms. The statistics also show a mean of 32.777 million naira for MDG which represents monetary donations and gifts to charity organisations and NGOs.. The maximum value is 79.9 million naira while the minimum is 6.67 million naira. The standard deviation of 27.72 million naira is low from the mean and indicates that there is not much variation in terms of donations for CSR activities by sampled firms.

Further, the statistics also show average number of physically challenged persons (EPC) on the employment of the sampled firms to be approximately 5 persons with a maximum and minimum value of 17 and 0 persons respectively. The minimum value shows that some sampled firms do not have physically challenged persons on their employment. Ratio of Expenditure on Staff Training and Development has a mean of 0.252 . The maximum and minimum values are 0.467 and 0.029 respectively 
with a standard deviation of 0.152 . The standard deviation shows considerable dispersion in ratio of expenditure on staff training and development among the sampled firms.

Finally, the variable of Community Based Project $(\mathrm{CBP})$ has a mean value of 7.4 projects. The statistics also indicate maximum and minimum values of 11 and 3 respectively. The standard deviation of 2.89 further depicts no significant variations in the distribution.

Table 2

Correlation analysis.

\begin{tabular}{c|c|c|c|c|c}
\hline VARIABLE & EMP & MDG & EPC & ETC & CBP \\
\hline EMP & 1.000000 & & & & \\
\hline MDG & -0.245583 & 1.000000 & & & \\
\hline EPC & 0.180599 & 0.126495 & 1.000000 & & \\
\hline ETC & 0.713878 & 0.299689 & -0.363552 & 1.000000 & \\
\hline CBP & 0.511573 & 0.532571 & -0.282210 & -0.223456 & 1.000000 \\
\hline
\end{tabular}

Source: Content analysis of financial statements.

KEY: EMP = Employee Performance; MDG = Monetary Donation and Gifts; EPC $=$ Employment of Physically Challenged; ETC $=$ Expenditure on Staff Training and Development; $\mathrm{CBP}=$ Community Based Projects

A correlation matrix is adopted to check the level of relationship between the dependent and independent variables on one part, and among the independent variable on the other. The correlation statistics shows that Employee Performance has a negative link with monetary donations and gifts ( $\mathrm{r}=-$ $0.245)$ and positive correlation with employment of physically challenged $(r=0.180)$; expenditure on staff training and development $(\mathrm{r}=0.713)$ and community based projects $(\mathrm{r}=0.511)$. The correlation table also indicates that MDG has a positive relationship with employment of physically challenged $(\mathrm{r}=0.126)$; expenditure on staff training and development $r=0.299$ and community based projects $(r=0.532)$.

Further, employment of physically challenged is seen to have a negative link with expenditure on staff training and development $(\mathrm{r}=0.363)$ and community based projects $(\mathrm{r}=0.282)$ while expenditure on staff training and development has a negative relationship with community based projects $(\mathrm{r}=-0.223)$

\subsection{Regression Results}

The regression results of the panel data estimation are reported in Table 3. The study used three estimators of panel data; pooled OLS, random effects and fixed effects in order to take cognizance of the dynamics of change with short time series, and thereby control for the effect of the unobserved heterogeneity in the dataset. The Hausman test was further conducted to validate the appropriate method in estimating the model which gave a probability value of 1.00 ( $p>0.05)$. Thus, the random effect was used in estimating the model.

The results of data analyzed are discussed thus:

Monetary donations and gifts (MDG) is found to have a negative and significant association with Employee performance $(\mathrm{EMP})$ at $5 \%$ significant level $\left(\beta_{1} M D G_{i t}=0.001247\right.$, Prob. $\left.=0.000\right)$. The result did not meet our a priori expectation. The implication of the result is that the level of monetary donations and gifts to charity organisations and NGOs as CSR activities does not positively influence productivity of employees.

Further, the coefficient of the variable Employment of the Physically Challenged (EPC) is observed to be positive and also significant $\left(\beta_{2} E P C_{i t}=0.003703\right.$, Prob. $\left.=0.000\right)$. This indicates that the employees' performance is significantly influenced by the employment of physically challenged persons in the organisation. The result met our a priori expectation. The implication of this finding is that as a firm engages in CSR activities in form of engagement of physically challenged persons, employees identify with the organization by improving on their productivity level.

The regression result on Expenditure on Staff Training and Development (ETC) variable shows a positive association and statistically significant at $5 \%\left(\beta_{s} E T C_{i t}=0.05464\right.$, Prob. $\left.=0.000\right)$. The result also 
indicates a $\operatorname{Prob}(0.000<0.05)$ which gives enough evidence to accept the hypothesis of a significant relationship between expenditure on staff training and development and employee performance. This position meets our apriori expectation and implies that as companies spend more on staff development productivity of employees will increase.

Table 3

Linear least square regression results.

Dependent Variable: EMP

Method: Panel EGLS (Cross-section random effects)

Swamy and Arora estimator of component variances

\begin{tabular}{|c|c|c|c|c|}
\hline Variable & Coefficient & Std. Error & t-Statistic & Prob. \\
\hline $\mathrm{C}$ & 0.007952 & $3.52 \mathrm{E}-16$ & $2.26 \mathrm{E}+13$ & 0.0000 \\
\hline MDG & -0.001247 & $3.64 \mathrm{E}-18$ & $-3.43 \mathrm{E}+14$ & 0.0000 \\
\hline $\mathrm{EPC}$ & 0.003703 & $1.32 \mathrm{E}-17$ & $2.81 \mathrm{E}+14$ & 0.0000 \\
\hline ETC & 0.054643 & $6.05 \mathrm{E}-16$ & $9.03 \mathrm{E}+13$ & 0.0000 \\
\hline \multirow[t]{3}{*}{$\mathrm{CBP}$} & 0.014308 & $3.58 \mathrm{E}-17$ & $4.00 \mathrm{E}+14$ & 0.0000 \\
\hline & \multicolumn{4}{|c|}{ Effects Specification } \\
\hline & & & S.D. & Rho \\
\hline \multicolumn{3}{|c|}{ Cross-section random } & 0.000000 & 0.0000 \\
\hline \multicolumn{3}{|c|}{ Idiosyncratic random } & $3.42 \mathrm{E}-16$ & 1.0000 \\
\hline & Weighted & tatistics & & \\
\hline R-squared & 1.000000 & \multicolumn{2}{|c|}{ Mean dependent var } & 0.103800 \\
\hline Adjusted R-squared & 1.000000 & \multicolumn{2}{|c|}{ S.D. dependent var } & 0.028121 \\
\hline S.E. of regression & $3.04 \mathrm{E}-16$ & \multicolumn{2}{|c|}{ Sum squared resid } & $4.15 \mathrm{E}-30$ \\
\hline F-statistic & $1.05 \mathrm{E}+29$ & \multicolumn{2}{|c|}{ Durbin-Watson stat } & 3.426733 \\
\hline \multirow[t]{2}{*}{ Prob(F-statistic) } & 0.000000 & & & \\
\hline & \multicolumn{4}{|c|}{ Unweighted Statistics } \\
\hline R-squared & 1.000000 & \multicolumn{2}{|c|}{ Mean dependent var } & 0.103800 \\
\hline Sum squared resid & $4.15 \mathrm{E}-30$ & \multicolumn{2}{|c|}{ Durbin-Watson stat } & 3.426733 \\
\hline
\end{tabular}

Concerning Community Based Projects (CBP), the result shows a positive and significant association with employee performance $\left(\beta_{5} C B P_{i t}=0.01430\right.$, Prob. $\left.=0.000\right)$. This implies that the level of community projects executed by a company is a significant determinant of the employee performance of food and beverages companies in Nigeria. This also meets our a priori expectation. We expected a significant positive association based on the fact that the community is part of the stakeholders of the business and employees are members of the host community.

\section{Conclusion and Recommendations}

The study investigated the influence of corporate social responsibility activities on employees job performance in Nigeria's listed Food and Beverages companies. The study adopted the content analysis approach and used content analysis of corporate financial statements to obtain relevant data from sampled food and beverages companies for the period 2014 to 2018. The study further deployed some descriptive, correlation and regression analyses to evaluate how the mean outcomes deviate from each other and establish the level of association between variables. The analysis indicated that employment of physically challenged, expenditure on staff training and development, and community based projects have a positive and significant association with employees' job performance. The findings of the study further revealed that monetary donations and gifts to charity organisations and NGOs have a negative and significant association with employees' job performance. The study concludes that corporate social 
responsibility practices enhances job performance of employees of Food and Beverages companies in Nigeria.

In line with the findings of this study, the following recommendations are proffered:

1. In view of the fact that CSR activities positively influence employees' job performance, corporate managers should embark on CSR dimensions that can improve welfare of employees and also well-suited with firm's overall strategy.

2. This study has identified that not all forms of CSR activities are capable of motivating employees of the firm. In this regard, firms need to properly recognize the type of CSR activities that their employees respond favorably to. However, this does not suggest that the scope of CSR activities of company's should not be extended.

\section{References}

Adeyemo, S. A., Oyebamiji, F. F., \& Alimi, K. O. (2013). An evaluation of factors Influencing corporate social responsibility in Nigerian manufacturing companies. International Journal of Academic Research in Economics and Management Sciences, 2(6), 54-63. Available at: https://doi.org/10.6007/ijarems/v2-i6/441.

Alkayed, D. (2017). The effect of corporate social responsibility on job satisfaction (Empirical study on Jordanian Private Hospital). European Journal of Business and Management, 9(12), 1-5.

Dutton, J. E., Dukerich, J. M., \& Harquail, C. V. (1994). Organizational images and member identification. Administrative Science Quarterly, 39(2), 239-263. Available at: https://doi.org/10.2307/2393235.

Edike, S., \& Otuya, S. (2018). Effect of social responsibility reporting on corporate performance in Nigeria. The Nigerian Accountant (A Journal of the Institute of Chartered Accountants of Nigeria), $51(2), 10-46$.

Gond, P. C., El-Akremi, A., Igalens, J., \& Swaen, J. (2019). Corporate social responsibility influence on employees. ICCSR Research Paper Serie, International Center for Corporate Social Responsibility, Nottingham University Business School, United Kingdom.

Greening, D. W., \& Turban, D. B. (2000). Corporate social performance as a competitive advantage in attracting a quality workforce. Business \& Society, 39(3), 254-280. Available at: https://doi.org/10.1177/000765030003900302.

Harvard Business Review. (2013). The impact of employee engagement on performance. Retrieved from https://hbr.org/resources/pdfs/comm/achievers/hbr_achievers_report_sep13.pdf.

Kilong'i, W. S., Ayora, J. M., \& Butali, P. (2019). Analysis of corporate social responsibility on organizational performance of water bottling companies in Garissa, Kenya. International Journal of Strategic Management and Procurement, 1(1), 80-87.

Lei, W. (2011). Factors affecting perception of corporate social responsibility implementation: An emphasis on values. PhD Dissertation of University of Helsinki.

Nigeria Stock Exchange. (2019). Stock market report. Retrieved from www.nse.com.ng/stockexchangenews/list. [Accessed 28th March 2019].

Omer, S. K. (2018). The impact of corporate social responsibility on employee's job satisfaction. Journal of Process Management, 6(3), 56-64.

Peong, H. K. (2019). The effect of corporate social responsibility and talent management on employee engagement (A Study at Tirta Komodo Regional Water Company, East Nusa Tenggara, Indonesia). Paper presented at the International Conference on Economics, Education, Business and Accounting, KnE Social Sciences.

Rahman, S. (2011). Evaluation of definitions: Ten dimensions of corporate social responsibility. World Review of Business Research, 1(1), 166-176. 
Sarfraz, M., Qun, W., Abdullah, M. I., \& Alvi, A. T. (2019). Employees' perception of corporate social responsibility impact on employee outcomes: Mediating role of organizational justice for small and medium enterprises (SMEs). Sustainability, 10(1), 1-19.

Setyaningrum, R. P., \& Haryono, T. (2018). The impact of CSR on employee performance: With the mediation of employee trust and employee behavior. Performance, 22(2), 200-219.

Shahin, A., Naftchali, J. S., \& Pool, J. K. (2014). Developing a model for the influence of perceived organizational climate on organizational citizenship behaviour and organizational performance based on balanced score card. International Journal of Productivity and Performance Management, 63(3), 290-307. Available at: https://doi.org/10.1 108/ijppm-03-2013-0044.

Shuli, G., \& Suwandee, S. (2017). Effect of corporate social responsibility on employee job performance: A case study of household products manufacturers in Southern China. Interdisciplinary Research Review, 12(5), 57-63.

Tsourvakas, G., \& Yfantidou, I. (2018). Corporate social responsibility influences employee engagement. Social Responsibility Journal, 14(1), 123-137. Available at: https://doi.org/10.1108/srj-09-20160153.

World Business Council for Sustainable Development. (2001). Corporate social responsibility: Meeting changing expectations. Geneva: World Business Council for Sustainable Development. 